\title{
Electrification of Colonial Calcutta: A Social Perspective
}

\author{
Suvobrata Sarkar* \\ (Received 14 April 2018; revised 17 May 2018)
}

\begin{abstract}
The public electricity supplies became available in Calcutta, second city of the Empire, as early as 1890 s and subsequently developed to become the major source of power both for industries and private use by 1940s. The Calcutta Electric Supply Corporation Ltd (CESC), with head-office in London, played the most vital part. This paper is an attempt to understand how electric light and power facilities were established and managed in Calcutta, and how they subsequently grew and changed. The bhadralok leadership acted as a pressure group and several times manipulated the direction of electrification of the city. The credentials of the Bengali erudite in the field of electricity, which this paper also tries to explore offers an interesting example of Indian response to the new knowledge.
\end{abstract}

Key words: Colonialism, CESC, Electricity, History of technology.

\section{INTRODUCTION}

Electricity is in many respects the 'foundational apparatus' upon which the experience of modernity has been instituted since the late nineteenth century. Electricity provides the essential infrastructure, one that enables several other types of infrastructure (Shamir, 2017). Western techno-scientific discourse occupied an extremely important place in the colonization of India. It is well-known that western technology and ideas manipulated various technological projects in the colony (Macleod and Kumar, 1995). While electrification has been one of the major areas of study in the history of technology in the last forty years, but in South Asian context we have a serious dearth of literature. The Madras Presidency has been fortunate to have the highest number of worksV R Muraleedharan (1991), and Y Srinivasa Rao (2007). Recently Leo Coleman's study (2017) reveals the power politics of colonial Delhi. By the middle of the twentieth century, electricity, with its elaborate infrastructure of wires, generation-stations and poles, emerged as the industrial era's most prominent symbol of progress in India including Calcutta. Here CESC played the most vital role - debated and resolved various technical questions, operated generation-stations, and electricity supply to industry and domestic purposes. Later, the Indian intellectuals participated and manipulated the development of electric power in the city. Could the electrification of Calcutta create new condition? What was the role of bureaucrats, politicians and specialistsboth European and Indian? What impact it had on the socio-economic condition of the city?

\section{The Formative Years}

Any discussion on the development of electricity in India should begin with Rookes Evelyn Bell Crompton (1845-1940). He was one of the pioneers who founded the British electrical industry. Crompton not only helped the Government of India in drafting the first Electricity

\footnotetext{
* Assistant Professor, Dept. of History, University of Burdwan, West Bengal; International Scholar, Society for the History of Technology (SHOT) for 2016 and 2017, Email: suvobrata.jnu@gmail.com
} 
Act, but also experimented the generation of the first unit of hydro-electricity in Darjeeling and was instrumental in the electrification in Calcutta through thermal power generation.

In 1896 Colonel Crompton was invited by the Government of India to assist in the preparation of a 'suitable' Electric Lighting Act. Although the first act to govern the matters related to electricity was the Electricity Act of 1887, but this was only a 'General Act' with no provision for the issue of licences to private entrepreneurs for the generation and distribution of electricity. In the last decade of the nineteenth century several private electrical firms offered the Bengal Government to supply electric light in Calcutta. The Calcutta Electric Lighting Act of 1895 threw open the door to competition. In 1897, Messrs Kilburn \& Co (agents of Indian Electric Co Ltd), secured the coveted Calcutta Lighting License for a period of twenty-one years. In a special meeting held in London (February 1897), the Indian Electric Co Ltd decided to change the name of the enterprise to CESC. Crompton himself was involved in the formation of CESC and had personally chosen the site for the station.

Crompton's long acquaintance with India, especially in the government circle, enabled him to overcome many difficulties, including local prejudices and superstitions against the use of electricity. He undertook several journeys to survey the far-flung areas of the city with a view to working out feasibility reports for electrification. The CESC wanted to use aerial lines in the streets of Calcutta supported on iron posts. They assured the government that with this system of distribution, the uncertainties existed in a tropical climate (humid condition) in using underground cables can be avoided.

But everything was not like cake-walk for the power company. One formidable opponent was C H Reynolds, Director-General of Telegraphs in India. His objection was against the overhead wires proposed to be erected by them. He understood that the CESC wanted to use overhead wires to minimize the cost but cautioned them about the security and convenience of the public. To melt the ice, Crompton had to intervene-his persuasion with Major P Cardew, Electric Adviser to the Government of India, enabled the power company to use aerial lines for the supply of electricity.

The first-generation station of the CESC commenced operation at Emambagh Lane, near Princep Street from April 17, 1899: following the most up-to-date practice then functioning in England, the company decided to adopt the three wire system of distribution (Edison system of distribution), supplying Direct-Current (DC) to consumers at 450 and 225 volts (Banerjee, 2002). Colonel Crompton had not only designed the plans and made blue-prints for operation, but also programmed the optimum efficiency of the plant.

\section{Period of Consolidation}

Thermal generation was first started in the city on a commercial scale by the CESC and with the passing of the Calcutta Electric Lighting License 1901; additional areas were placed under the purview of the company. When electricity first came to Calcutta no one could have imagined that the days of the hand-pulled punkhāh were numbered. The popularity of the electric fan ensured immediate success for CESC and provided the 'day-load', essential to the economic working of an electric supply station. The growing demand for electric current for lights as well as fans necessitated the enlargement of the Emambagh Lane station from time to time, and extension of the distribution mains. Additional DC generating stations were opened in different parts of the city-Alipore in March 1902 (750 KW), Howrah in May 1906 (165 KW), and Ultadanga in September 1906 (1200 KW).

The Imperial Government preferred the industrial supply of energy for factories which was more important than the supply of energy for 
traction, lighting and fans. There were incentives for the power company also. With the rapid increase in demand for power for jute presses and mills, the CESC decided to install an Alternating Current (AC) plant at the Ultadanga station to deal with the pressing needs of consumers of the northern part of Calcutta. Supply from this station was available from September 1910. Now CESC applied to the Bengal Government to supply electrical energy at a standard pressure from 6000 to 6600 volts to meet the demands of large consumers (jute presses). Sanction came quickly with a condition - 'The word Danger, both in English and in the vernacular, shall be affixed in a conspicuous position near every motor, switch board or regulator apparatus in connection with the supply.' ${ }^{1}$ To attract large consumers, the CESC also proposed certain special rates of electricity. The special power rate was applicable to those who had installed not less than $10 \mathrm{KW}$ in one motor or as an aggregate of motors not less than one KW each.

By now the advantages of having a large central station generating Alternating Current at high voltage and supplying sub-stations in different parts of Calcutta where AC could be converted to DC were felt. The River Hooghly, the life-line of Calcutta, on both banks of which industrial units had sprung up, could provide the water necessary to run a large power plant. Cossipore was selected as a project-site (1910) and, as the first central thermal generation station with an initial installed capacity of $15 \mathrm{MW}$, it started generating Alternating Current at 6000 volts from July 1912 (Sarkar, 2018). In 1926 when the power company decided further expansion, the site of the Southern Generating Station at Garden Reach with an initial capacity of $22.5 \mathrm{MW}$ was once again selected, like Cossipore, on the riverbank. The capacity of the station was subsequently augmented to $110 \mathrm{MW}$ and eight turbo-generator and 15 boilers were installed in the station.

But technologically, the most important link between the River Hooghly and CESC was formalized when a tunnel was built under the river to carry cables from one bank to another in 1929. Miss Eileen Homan, daughter of the then Chief Executive of CESC, Mr F T Homan, inaugurated and work started on underground tunnel between Southern Generating Station and Botanical Garden, Howrah. This unique engineering feat was completed in 1931. Looking at the busy industrial complex on both sides of the River Hooghly today, it is difficult to imagine how the modern wizard electricity acted as an agent of development! The Mulajore Generating Station was perhaps the last engineering feat dedicated to serve Calcutta before independence. The electric supply company completed the construction of this power station in 1940 to meet the growing industrial production and commenced work on the New Cossipore Generating Station to augment the capacity of the old station at Cossipore.

\section{Response and Resistance}

There was no dearth of inquisitiveness in the traditional Bengali society and from the beginning they displayed their credentials in the field of electricity. Here one incident is worth a mention. An attempt was made to light the old Howrah Bridge with a private source of electricity in the late nineteenth century. One Jawaharlal Dhar, self-styled electrician, actively participated in the project. Aware of his technological curiosity, Mr Fischer, Managing Agent of the Indian Electric Light Company, recruited Dhar at a salary of 100. When the electrification of the Eden Garden was carried out by the company, Jawaharlal also worked there. But due to a minor dispute with one German engineer of the project, he left the place. Later, Dhar joined the Emerald Theatre and 
produced electricity to light the premises with the help of a steam-driven machine (Dhar, 1896, pp. 85-9).

In Calcutta, the entire urbanization process was initiated by the British out of imperialistic motivations. Hence, lighting scheme (here with electricity) can also be viewed as a part of that infrastructure which was imported into India to facilitate further expansion. This can be seen from the simple fact that the Oriental Gas Company, Calcutta Tramways Company, along with CESC, were all British-owned private companies based in London. But the course of development of technology was also influenced by the people that were at the receiving end (Arnold, 2013). The Calcutta Corporation, which played a constructive role in building a modern nation-state, had contributed in the process of assimilation of modern technology, to a significant extent.

The triumph of the Swaraj Party in the municipal elections of 1924 opened the doors of the Calcutta Corporation to the nationalist Indians led by C R Das (1870-1925). But the Corporation possessed neither the financial resources nor the administrative jurisdiction for implementing their full programme. It had no power to do anything in the field of electric and gas supply, which was contracted to British companies. Despite all these limitations, the Corporation tried to stimulate indigenous industries. Inevitably, European big business in Calcutta was angered by the role of the Corporation. Particularly serious, from the point of view of European big business, was the sharp conflict between the Congress-controlled Calcutta Corporation and the British-incorporated Calcutta Electric Supply Corporation.

From the beginning of the Civil Disobedience Movement (1930) the Swarajist Corporation had continuously pressurized the CESC, which had a monopoly of electric supply in Calcutta, to reduce the rates of electricity. In
1930, the Corporation managed to persuade the British company, by a fierce public agitation, to reduce the rate from 3 annas per unit to $2 \frac{1}{2}$ annas per unit. This did not satisfy the Corporation, which argued that the rate be further reduced, to 2 annas per unit. Further agitation induced the Government to reduce the rate to 2 annas per unit (Sarkar, 2015).

Towards the end of the 1930s, another kind of opposition began to emerge among the political, business and educated elite communities. This was against the domination of British electrical corporation. Not content with the reduction in the rates on electricity, the Corporation went on to propose an end to the monopoly of electric supply by the CESC. At the beginning of the Civil Disobedience Movement, a Bengali engineer, Dr B N Dey, was appointed as Chief Engineer by the Corporation. He immediately drew up a scheme for generation of electricity by the Corporation which emphasized,

\section{'... if the gas lamps of the city were converted into electric lamps and each burner was replaced by 75 watt electric lamps, Calcutta will get $51 \%$ better lighting and the net annual saving to the Corporation will be about Rs 3,65,000.' ${ }^{2}$}

On the basis of Dey's plan, the Calcutta Corporation submitted to the Government, for its sanction, an electricity scheme under which the Corporation would produce its own electricity, at rates lower than those charged by the British company. The Government kept quiet, as it affected the vested interests of the British capital.

The Corporation even exerted continuous pressure on the Government of Bengal for the option to purchase the CTC and CESC on the expiry of their license in 1938. But that didn't materialize at that point of time. Rajat Ray has demonstrated the change in the balance of forces in the arena of municipal politics as the vastly improved position of the CESC vis-à-vis the 
Calcutta Corporation, after the new Muslim ministry came into power in 1937 , based on the Government of India Act of 1935 (Ray, 1979).

Science \& Culture, a leading journal, once identified the electricity supply as a public utility concern and thus the every civilized country of the world has taken steps for 'full development of its power resources, for adequate control of the production of electrical energy and for ensuring the public of a cheap supply and protecting them from profiteering and exploitation. ${ }^{3}$ But Calcutta was perhaps an exception and the result was obvious: 'The rate at Calcutta was about eight times greater than that at London.' The private supply companies in India enjoyed several special privileges over their counterparts in England. CESC had the monopoly in this sector. Then also the rate of electricity was so high at Calcutta. Once the journal identified cheap and abundant power supply as utmost important considering the industrial efficiency of a nation entirely depended upon it. The power resources should be regarded as national assets and it further recognized that development of cheap and abundant power was a prime-duty of the state. The logical culmination of such demands was nationalizing the power sector.

The demand for nationalization was further accelerated by the National Planning Committee, appointed under the chairmanship of Jawaharlal Nehru in 1938. The Sub-Committee, 'Power \& Fuel', recognized that a well-organized and well distributed national system of generation and distribution of electrical power could be met, only if the entire enterprise of production as well as the supply of this energy was made a public utility concern (Shah, 1947, p.128). The desire for Indianization was not fulfilled immediately even after independence. Two decades later when the directors of CESC decided that the industrial supply of power to Calcutta would have to be managed and controlled by an Indian company, only then the control of the company was transferred from London to Calcutta in 1970.

\section{Conclusion}

The socio-cultural condition of a colonized Asian society was markedly different from their European and American counterparts. In Calcutta the relocation of electrical technology by the agency of colonial regimes (British Government) and through the distributive networks of international business organization (CESC); went through significant local amendment to suit to the local condition. The foreign power company had to negotiate at the multiple levels - the Central Government, Provincial Government, Municipal Body, and of course with the Indians as consumers, sometimes collaborators, as well as contenders. Another significant point is that when various electrical utilities were disseminated from the west (place of invention) to the indigenous masses, including elites (place of reception), the cultural significance of these electrical-goods might change. Here the local population get significant share in the evolution of modern technology. Thus, to understand technology's social fashioning in a colonial Asian context, one needs to consider the local patterns, needs and logic.

\section{ACKNowledgement}

Based on the two earlier publications, this version originally presented at an international conference, "Emergence of Modern Science in Colonial India", INSA, New Delhi, 14-16 March 2018. The author is grateful to Prof Arnab Rai Choudhuri and INSA for the opportunity. The comments and suggestions of Prof Deepak Kumar, Prof Suranjan Das, Prof Smritikumar Sarkar, Prof Ranjan Chakrabarti, Prof Ross Bassett, Dr John Lourdusamy, Dr John Mathew, Dr Madhumita Mazumdar, and Dr Aparajith Ramnath, at various

${ }^{3}$ Science \& Culture, Vol. I, No. 7, December 1935, p. 367. 
stages, are beneficial. Special thanks are due to Mr Madhvendra Narayan, Associate Editor of IJHS, for help and care in publication.

\section{BIBLIOGRAPHY}

Arnold, David. Everyday Technology, University of Chicago Press, Chicago and London, 2013.

Banerjee, Sumanta. Hundred years of electricity in Calcutta, Indian Journal of Power and River Valley Development, 52.7 \& 8 (2002): 119-125.

Coleman, Leo. Electrification as Political Ritual in New Delhi, Speaking Tiger, New Delhi, 2017.

Dhar, Jawaharlal. Sachitra Kolikata-Rahasya, Sri Akhilchandra Shil, Kolikata, (1303 BS), 1896.

Hughes, Thomas P. Networks of Power, Johns Hopkins University Press, Baltimore and London, 1983.

Macleod, Roy and Kumar Deepak (eds.). Technology and the Raj, Sage, New Delhi, 1995.

Muraleedharan, V R. The Electrification of Madras City 1905 to 1914 , paper presented at the Third World Economic History and Development Conference, University of Manchester, September 13$15,1991$.
Miscellaneous Public Improvement Branch of the Public Works Department, West Bengal State Archives (WBSA), Kolkata.

Proceedings of the Home Department and Public Works Department, National Archives of India (NAI), New Delhi.

Rao, Y Srinivasa. Electrification of Madras Presidency, 1900-1947, unpublished PhD Thesis, IIT Madras, 2007.

Ray, Rajat. Urban Roots of Indian Nationalism, Vikas, New Delhi, 1979.

Sarkar, Suvobrata. Electrification of colonial Calcutta: Role of the Innovators, Bureaucrats and Foreign Business Organization, 1880-1940, Studies in History, 34.1 (2018): 48-76.

Sarkar, Suvobrata. Domesticating electric power: Growth of industry, utilities and research in colonial Calcutta, The Indian Economic and Social History Review, 52.3 (2015): 357-89.

Shah, K T. (ed.). Power \& Fuel, National Planning Committee Series, Vora \& Co, Bombay, 1947.

Shamir, Ronen. Electricity and Empire in 1920s Palestine under British Rule, NTM Journal of the History of Science, Technology \& Medicine (Online First): DOI 10.1007/s00048-017-0161-z , 2017. 